\section{FIRST RECORD OF GALEODES INDICUS POCOCK, 1900 (ARACHNIDA: SOLIFUGAE: GALEODIDAE) FROM RAJASTHAN, INDIA}

\section{Ruquaeya Bano ${ }^{1} \&$ Sharmila Roy ${ }^{2}$}

${ }^{1}$ Zoological Survey of India, Western Regional Centre, Vidyanagar, Sector-29, P.C.N.T. Post Rawet Road, Near Akurdi Railway Station, Akurdi, Pune, Maharashtra 411044, India

${ }^{2}$ Central Arid Zone Research Institute, Jodhpur, Rajasthan 330363 India

${ }^{1}$ banoruquaeya@rediffmail.com (corresponding author),

${ }^{2}$ roysharmilaigfri@gmail.com

Solifugids are moderately small to large spider-like, nocturnal, cursorial and hunting creatures belonging to the order Solifugae. They are commonly known as wind spiders or sun spiders and are found in arid, semi-arid habitats worldwide (Muma 1966; Wharton 1987; Gajbe 2005). They eat small insects and other arthropods by crushing and chewing with the help of their large jaws (Image 1). Solifugae have a well-developed tracheal system instead of book lungs. They have adhesive organs on the ends of pedipalps (Image 2), called the suctorial organs (Cushing \& Castro 2012). The females of the species have fan-shaped organs called malleoli on the ventral surfaces of the hind legs (Image 3).

Solifugae consist of well over 1,116 described species worldwide belonging to 13 families and 144 genera and are generally believed to be the sister group to the Pseudoscorpions (Harvey 2002). There are 201 species belonging to nine genera under the family Galeodidae distributed worldwide, but in India, family Galeodidae is represented by a single genus Galeodes
Olivier, 1791 comprising 13 species.

This study was conducted in the arid rangelands of Jaisalmer District in western Rajasthan, India, to assess the diversity of soil micro arthropods in fodder grassland. The geographical position of the site is $26^{\circ} 59467^{\prime \prime} \mathrm{N} \& 71^{\circ} 20164^{\prime \prime} \mathrm{E}$ near Jaisalmer City.

Lasiurus sindicus Henrard

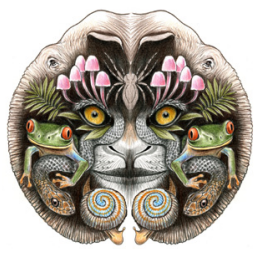

ISSN 0974-7907 (Online) ISSN 0974-7893 (Print)

\section{OPEN ACCESS}

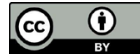

commonly known as Sewan grass is a bushy, multi branched, perennial desert grass with thin leaf blade and woody rhizome. It is used for pasture and fodder for livestock, mainly grazed by ruminants and is palatable pasture for camels (Bhati \& Mruthyunjaya 1983; Mertia et al. 2006). It is the primary grass of extremely arid parts of Jaisalmer, Bikaner and Barmer districts of western Rajasthan (Bhati \& Mruthyunjaya 1983). The soil is slightly calcareous, coarse-textured, light-brown and sandy and has a low moisture-retention capacity.

During the regular collection of soil micro arthropods by pitfall trap in Lasiurus sindicus grassland we came across an interesting specimen of the genus Galeodes sp. inside the pitfall along with other soil arthropods on 11 March 2014 at Chandan Village. The dead specimen was examined under a Lawrence \& Mayo stereo zoom microscope following Pocock (1900) and photographed using Leica EZ4HD Integrated 3.0 mega pixel CMOS Microscopic Camera and the specimen was deposited at the National Zoological Collection, Zoological Survey of India, Western Regional Centre, Pune, for further analysis. All the measurements are represented in the millimetres.

DOI: http://dx.doi.org/10.11609/jott.2655.8.3.8623-8625 | ZooBank: urn:Isid:zoobank.org:pub:E528842D-4DCE-4C41-9B73-6D3F9E075152

Editor: Anonymity requested.

Date of publication: 26 March 2016 (online \& print)

Manuscript details: Ms \# 4270 | Received 14 March 2015 | Final received 01 January 2016 | Finally accepted 12 March 2016

Citation: Bano, R. \& S. Roy (2016). First record of Galeodes indicus Pocock, 1900 (Arachnida: Solifugae: Galeodidae) from Rajasthan, India. Journal of Threatened Taxa 8(3): 8623-8625; http://dx.doi.org/10.11609/jott.2655.8.3.8623-8625

Copyright: (C) Bano \& Roy 2016. Creative Commons Attribution 4.0 International License. JoTT allows unrestricted use of this article in any medium, reproduction and distribution by providing adequate credit to the authors and the source of publication.

Funding: None.

Conflict of Interest: The authors declare no competing interests.
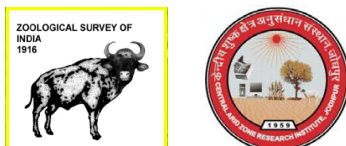

Acknowledgments: The authors are grateful to Dr. Kailash Chandra, Director, Zoological Survey of India, Kolkata and Dr. M.M. Roy, Director Central Arid Zone Research Institute, Jodhpur (Rajasthan) for facilities and encouragements. 
Galeodes indicus Pocock, 1900 (Images 1-3)

Material examined: SLF/01, 1ex. (immature), 11.iii.2014, Lasiurus sindicus grassland, Chandan Village, Jaisalmer, Rajasthan $\left(26^{0} 59467^{\prime \prime} \mathrm{N} \& 71^{\circ} 20164^{\prime \prime} \mathrm{E}\right)$, coll. S. Roy (Table 1).

Distribution: Jaisalmer, Rajasthan (new record), Gwalior (Madhya Pradesh), Bilaspur (Chhattisgarh), Gaya (Bihar), Thane (Maharashtra), Kurnool (Andhra Pradesh).

A distribution map (Fig. 1) for Galeodes indicus Pocock, 1900 in India is provided based on the published literature and present record made from Chandan Village, Jaisalmer, Rajasthan.

The collected specimen was identified as a member of family Galeodidae readily distinguished from other members of the order Solifugae by tarsus of palp narrow at base and freely articulated to tibia; stalk of claws hairy.

Diagnosis Female (Image 3): The collected specimen was identified as a female specimen by the presence of stalked, leaf-like chemosensory structures called malleoli or racquet organs on the ventral side of coxae and trochanters of the fourth pair of legs. Head infuscate, legs and palpi a tolerably uniform yellowish-brown. Coxae of both palpi clothed with numerous stout hairs; about 15-16 short spines on trochanter of palp; femur of palp armed with seven pairs of long spines; Patella of palp armed below with eight pairs of long-seti-form spines, of sub-equal thickness and alternating in length. Tibia similarly armed below with 11 pairs of longer and shorter spines, half of them on each side being very long and setiform, and slightly stouter than others. Tarsi of palpi armed with eight pairs of long hairs. Distal tarsal segment of fourth leg is spined. Blade of external malleolus slightly exceeding the ocular tubercle.

Galeodes indicus Pocock, 1900 is reported for the first time from Rajasthan. Wind scorpions are a little known group in Indian fauna. Pocock (1900) reported three species from central India, namely Galeodes fatalis Lichtenstien \& Herbst, G. orientalis Stoliczka and G. indicus Pocock. Pocock (1900) reported Galeodes indicus species from Bilaspur, Chhattisgarh, and further described two subspecies, namely obscurior from Pimpalner, East Khandesh (Maharashtra) and australis from Secunderabad (Telangana). Presently subspecies obscurior is synonymized with Galeodes indicus (Whittick 1939) and australis recognized as a full species (Harvey 2003). Distribution wise Galeodes indicus Pocock is reported from various regions of the India namely Gwalior (Madhya Pradesh), Bilaspur (Chhattisgarh), Gaya (Bihar), Thane (Maharashtra) and Kurnool (Andhra Pradesh). The present record of the Galeodes indicus

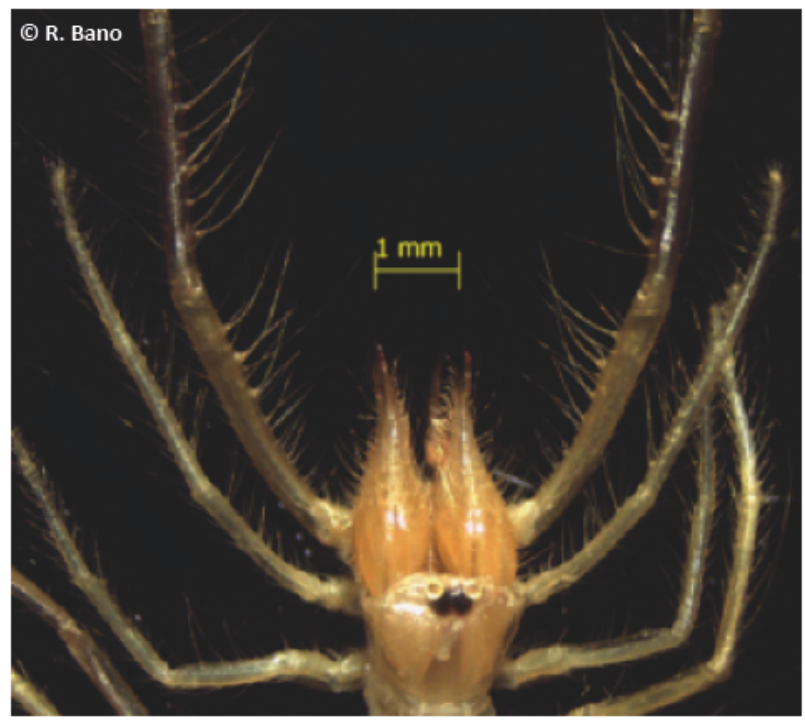

Image 1. Head bearing strong jaws and eyes

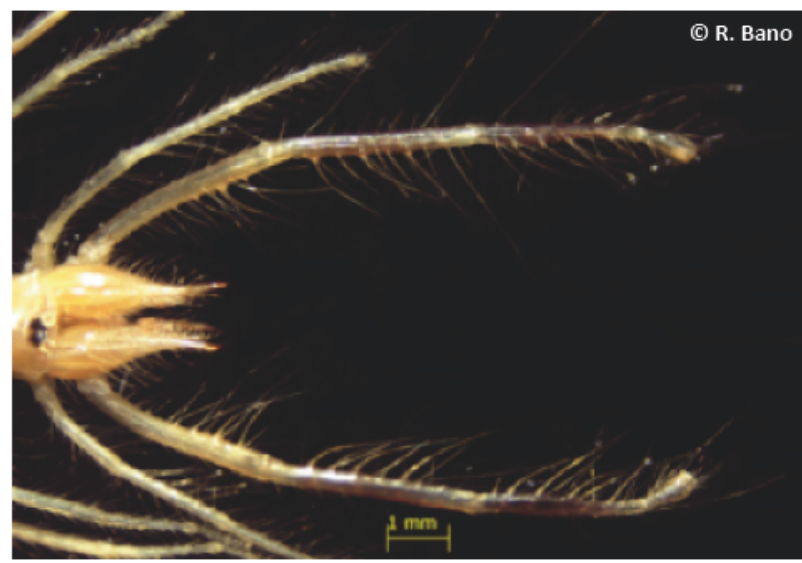

Image 2. A pair of Pedipalp with adhesive organs

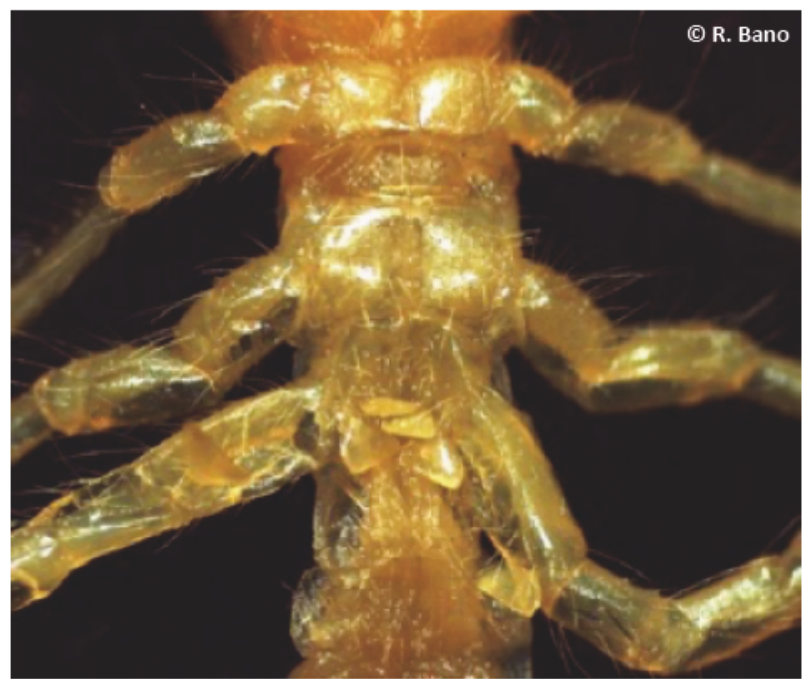

Image 3. Fan-shaped Malleoli or Racket organs present on ventral side of fourth legs 


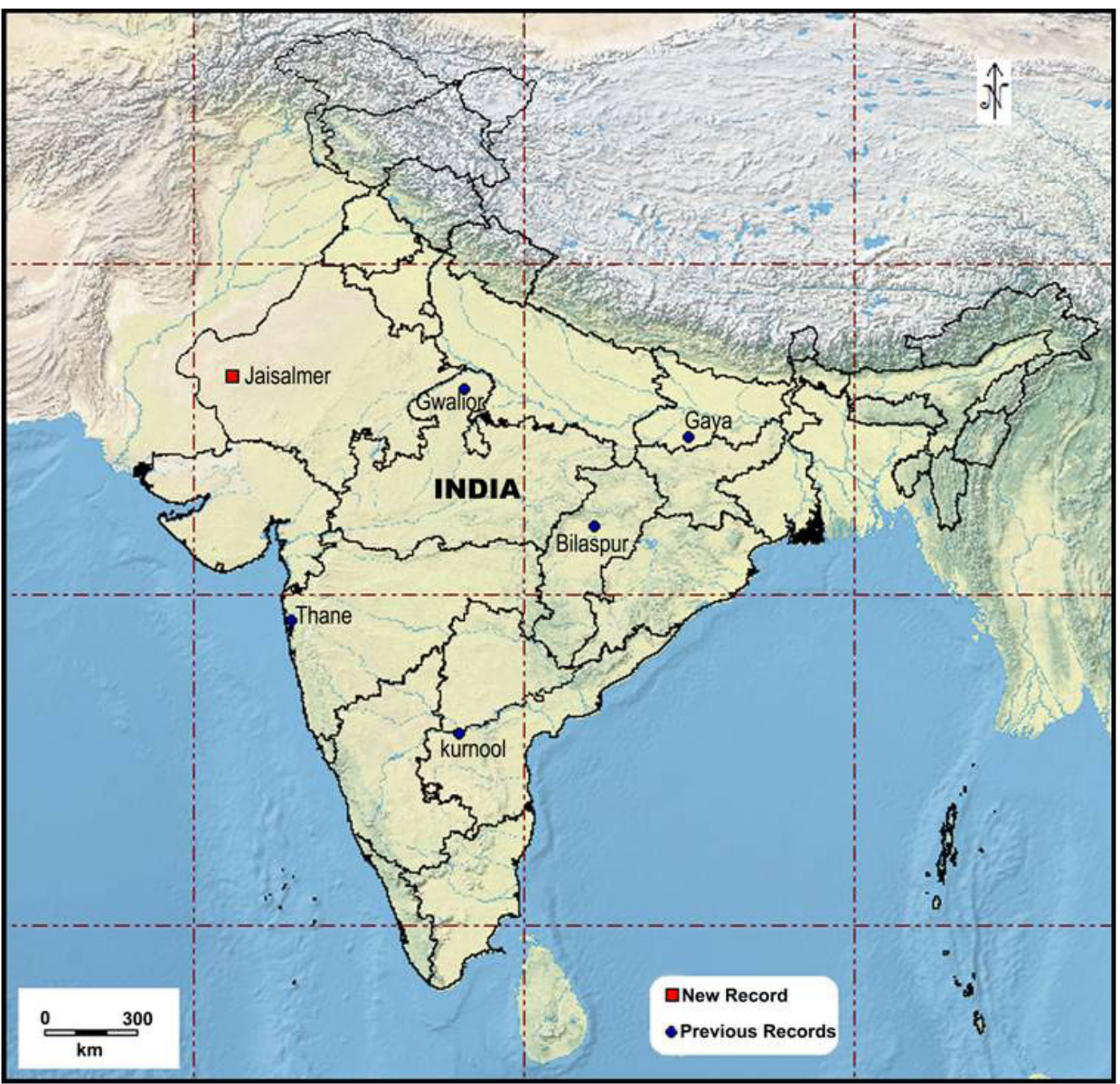

Figure 1. Distribution records of Galeodes indicus Pocock, 1900

Table 1. Measurements of body parts in $\mathrm{mm}$

\begin{tabular}{|l|c|c|c|c|c|c|c|}
\hline & $\begin{array}{c}\text { Total } \\
\text { Length }\end{array}$ & $\begin{array}{c}\text { Width of } \\
\text { Head }\end{array}$ & $\begin{array}{c}\text { Length of } \\
\text { Mandibles }\end{array}$ & Length of Palpi & Leg I & Leg II & Leg III IV \\
\hline Female & 10 & 2 & 2 & 12 & 8 & 7 \\
\hline
\end{tabular}

from Chandan Village, Jaisalmer District is the first report of the species from the Rajasthan region.

\section{References}

Bhati, G.N. \& Mruthyunjaya (1983). Economics of sheep farming on different pastures in arid land of western Rajasthan. Indian Journal of Animal Sciences 53 (7): 732-737.

Cushing, E.P. \& P. Casto (2012). Preliminary survey of the setal and sensory structures on the pedipalps of camel spiders (Arachnida: Solifugae). Journal of Arachnology 40(1): 123-127; http://dx.doi. org/10.1636/B11-71.1

Gajbe, P. (2005). First record of a wind-scorpion Arachnida Solifugae from Seoni District, Madhya Pradesh. Journal of the Bombay Natural History Society 102(2): 249-250.

Harvey, M.S. (2002). The neglected cousins: What do we know about the smaller Arachnid orders? Journal of Arachnology 30: 357-372; http://dx.doi.org/10.1636/0161-8202(2002)030[0357:TNCWDW]2 .0.CO;2
Harvey, M.S. (2003). Catalogue of the Smaller Arachnid Orders of the World: Amblypygi, Uropygi, Schizomida, Palpigradi, Ricinulei and Solifugae. CSIRO Publishing, Collingwood, Australia, 363pp.

Mertia, R.S., R. Prasad, B.K. Kandpal \& P. Narain (2006). Regeneration of Lasiuruss indicus in relation to grazing pressure and root-zone soil moisture in arid rangelands of western Rajasthan (India). Tropical Grasslands 40: 40-44.

Muma, M.H. (1966). Burrowing habits of North American Solpugida (Arachnida). Psyche 73: 251-260.

Pocock, R.I. (1900). The Fauna of British India, Including Ceylon and Burma Arachnida. Taylor and Francis, London, 279pp.

Wharton, R.A. (1987). Biology of the diurnal Metasolpugapicta (Kraepelin) (Solifugae, Solpugidae) compared with that of nocturnal species. Journal of Arachnology 14: 363-383.

Whittick, R.J. (1939). Notes on Solifugae (Arachnida)-I. Galeodidae. Annals and Magazine of Natural History 11(4): 444-450. 